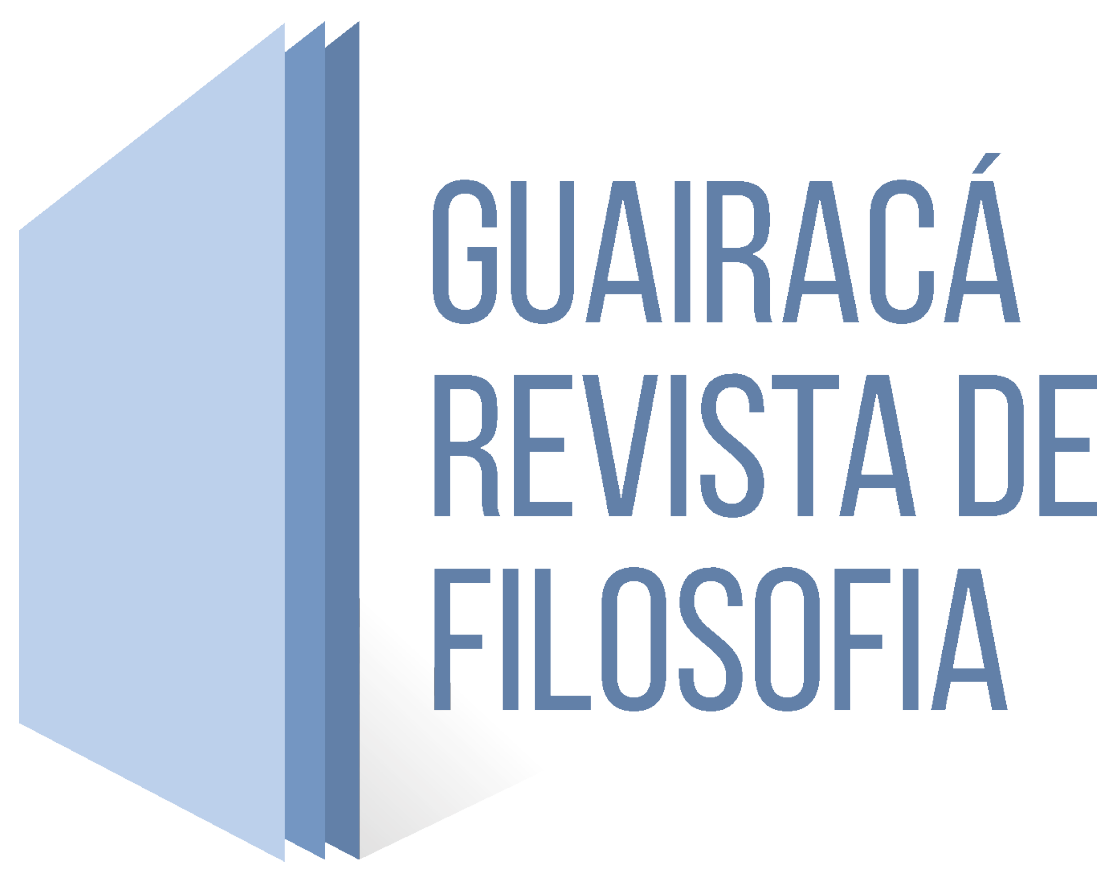

\title{
A ERRÂNCIA DO FILÓSOFO PLATÔNICO: DOGMATISMO, IGNORÂNCIA E APORIA
}

Resumo: Para fazer frente ao dogmatismo costumeiramente atribuído ao platonismo, o presente artigo discute a figura do filósofo através de dois conceitos: o intermediário (metaxý) e a ignorância enquanto errância psíquica (plánē). Defendese que o primeiro conceito, presente em mais de um diálogo, é fulcral para a compreensão da figura do filósofo e opõe-se a uma postura dogmática. Argumentase igualmente que a ignorância como errância psíquica caracteriza não apenas o estado aporético experimentado pelos interlocutores de Sócrates, como também a experiência do próprio filósofo. Nesse sentido, pode-se falar de uma errância do filósofo platônico, a qual novamente aponta para a ausência de dogmatismo. Os dois conceitos enfatizam o elemento de incompletude que define o filósofo platônico e se baseiam, respectivamente, na consciência da ignorância e na dificuldade de lidar com os conceitos universais próprios da filosofia.

Palavras-chave: Platão; dogmatismo; ignorância; aporia; filósofo.

1. Doutor em Filosofia pela UFSC. Professor de filosofia da UFPR. E-mail: reusengler@gmail.com. 


\title{
THE WANDERING OF THE PLATONIC PHLLOSOPHER: DOGMATISM, IGNORANCE AND APORIA.
}

\begin{abstract}
In order to face the dogmatism usually ascribed to Plato, I discuss in this paper the figure of the philosopher on the basis of two concepts: the philosopher's intermediate position (metaxý) and the ignorance qua psychic pláne. I defend that the first concept, which appears at least in three dialogues, is paramount to the understanding of the figure of the philosopher and opposes itself to a dogmatic posture. I argue as well that ignorance qua psychic pláne (wandering) characterizes not only the aporetic state that Socrates' interlocutors undergo, but also the experience of the philosopher himself. In this regard, one can talk of a wandering of the platonic philosopher which points out, again, to the absence of dogmatism. Both concepts emphasize the element of incompleteness that defines the platonic philosopher. They are based on the consciousness of one's own ignorance and on the difficulty of dealing with the universal concepts of philosophy.
\end{abstract}

Keywords: Plato; dogmatism; ignorance; aporia; philosopher.

Errare mehercule malo cum Platone, quem tu quanti facias scio et quem ex tuo ore admiror, quam cum istis vera sentire ${ }^{2}$. Cicero, Tusculanae Disputationes, I, xvii, 37-40.

\section{0 DOGMATISMO DE PLATÃO E A FIGURA DO FlLÓSOFO}

Por maiores que sejam os sucessos da longa tradição exegética da obra platônica, ainda é comum que se compreenda Platão como o filósofo dogmático por antonomásia. O adjetivo "platônico" costuma ser aplicado a qualquer coisa de etéreo e ideal - haja vista o dito "amor platônico" - ao mesmo tempo em que denota a posse de um saber seguro sobre realidades imutáveis, divinas e perfeitamente cognoscíveis pelo entendimento do filósofo. Nas distinções manualísticas da epistemologia, por exemplo, Platão é um téorico fundacionista que se opõe àqueles filósofos para quem o conhecimento humano é falho ou relativo, como Protágoras, Hume ou Quine. Na metafísica, Platão é considerado ainda mais dogmático, pois

2. "Pelos céus, prefiro andar a esmo com Platão (sei por quão grandioso o tomas), a quem aprendi de tua boca a admirar, do que sustentar opiniões verdadeiras na companhia desses [seus oponentes]" (Tradução minha). 
que desdenha a configuração sensível de todas as entidades - inclusive de coisas óbvias como o corpo - para reencontrar sua verdadeira natureza reduplicada em um plano suprassensível. Na esfera ética, por sua vez, a tese de quem ninguém erra voluntariamente e de que as paixões devem ser domesticadas pela razão dá a impressão de um pensador racionalista e ascético, que apregoa ideais morais inatingíveis pelo homem médio. $\mathrm{Na}$ área política, sua fidelidade às procústeas deduções da razão parece fazer dele um tirano da pior espécie, contrário a toda a abertura da sociedade. Na estética, por fim, sua crítica aos aspectos miméticos e emotivos da poesia deixa emergir a figura de um filósofo casmurro e puritano, que em virtude de suas insensíveis opiniões não consegue desfrutar da beleza cativante dos versos de Homero. De uma forma ou de outra, essas apreciações da obra de Platão são ainda bastante encontradiças quer em livros didáticos, quer em livros específicos de filosofia antiga ${ }^{3}$.

Contudo, há indícios incontornáveis de sua parcialidade. $\mathrm{O}$ primeiro deles está na própria tradição de comentário a Platão, a qual, quando açambarcada em suas diversas configurações históricas, aponta para a inexistência de uma imagem derradeira do platonismo. Ao contrário, cada escola hermenêutica enfatiza certos temas e diálogos e forma, ao fim e ao cabo, versão sui generis da doutrina de Platão. Enquanto pensadores da própria Academia compreenderam seu mestre como um predecessor do ceticismo, por exemplo, os primeiros padres e gnósticos admiraram o lado religioso de Platão e o tomaram por seu aliado na tarefa de anunciar a verdade revelada (GILSON, 1998, p. 4; 25). As duas posições não poderiam ser mais opostas e, não obstante, podem ser igualmente derivadas dos Diálogos. Na verdade, a obra platônica dá azo a tantas interpretações, que eminentes estudiosos do século XX chegaram a propor que Platão jamais expressou sua verdadeira doutrina de forma escrita, mas apenas em preleções orais cujo real conteúdo, conservado em fragmentos por uma tradição indireta, eles pretendem redescobrir com métodos hermenêuticos atualizados (REALE, 1997; SLEZÁK, 2005). A tese das doutrinas não-escritas, em que pese a correção de alguns de seus pontos, soa como um desespero exegético da parte do honesto intérprete que, perquirindo as diferentes posturas de Platão, não consegue alcançar conclusão cabal e precisa recorrer a um ponto de vista externo para dar coerência à miríade de ideias dos Diálogos. O mesmo seja dito da tese de Léo

3. Sobre a estética, pode-se conferir o livro de Haar (2000, p. 22-25), que empreende leitura literalíssima de Platão e, por conseguinte, em nenhum momento nota o fato contraditório e altamente significante de que, na composição de sua própria obra, Platão utiliza todos os meios poéticos disponíveis que depois critica em Homero. O termo "puritano" advém da crítica de Halliwell (2002, cap. II), que define Platão como um puritano romântico, por valorizar a imaginação e, ao mesmo tempo, temer seu poder. Sobre o racionalismo e o ascetismo na ética, pode-se conferir o clássico de Martha Nussbaum (2009), ainda que a autora veja tais fatos como uma fase do platonismo depois superada. Sobre a epistemologia e a metafísica, encontram-se exemplos em filósofos como Kant (1967), na Crítica da Razão Pura, e Quine (1975), no célebre Sobre o que há. No que toca à política, confira-se o estudo de Popper (1987). 
Strauss (1964, p. 50) e seus discípulos, para quem Platão tampouco expressou seu pensamento via escrita: supor um conteúdo esotérico para o platonismo significa, em última instância, admitir a impossibilidade de encontrar sentido para o que se lê nos Diálogos.

Naturalmente, há exceções no interior desse panorama. Porém, a maioria dos estudiosos que logra apresentar tal ou qual unidade doutrinária arrima-se ainda no paradigma hermenêutico da filologia do séc. XIX: o desenvolvimentismo. Defendendocom argumentos majoritariamentefilológicos a evolução do pensamento platônico e a consequente quebra com os diálogos intermediários, esses estudiosos são capazes de mostrar que o Platão da senectude alterou radicalmente suas ideias". Esse Platão parece muito mais moderno e não exclui de todo, por exemplo, o estudo da natureza e o conhecimento empírico, assim como é mais brando em relação às paixões e mais realista em termos de política (cf. KAHN, 2013). No fim, formulase imagem mais ou menos coerente do platonismo. Todavia, esta visão padece de graves problemas, como o fato de não ser citada por nenhum autor antigo. Aristóteles, com efeito, ignora qualquer evolução ou quebra de pensamento de seu mestre, pois menciona indistintamente diálogos que pertenceriam a épocas distintas, como o Fédon e o Timeu. E, ademais, a única organização dos Diálogos legada pela Antiguidade, a de Trásilo, baseia-se em critérios dramáticos e de conteúdo, fazendo com que a segunda tetralogia (Crátilo, Teeteto, Sofista, Político), por exemplo, abarque diálogos que, consoante a perspectiva moderna, pertenceriam à maturidade e não poderiam seguir os diálogos da primeira tetralogia (Eutífron, Apologia, Fédon, Criton). Por esses e outros motivos, o desenvolvimentismo está sendo atacado em seus alicerces; parece mesmo que se aproxima o tempo em que suas teses deixarão de ser tomadas por óbvias ${ }^{5}$.

Tal riqueza de interpretações já deveria servir como indício, portanto, de que Platão talvez não seja tão dogmático como ainda hoje se acredita. Afinal, se ele o fosse, seria decerto mais fácil entrar em acordo sobre sua doutrina e expô-la de tal sorte que angariasse o consentimento da maioria dos estudiosos. Mas esse é um feito que infelizmente ainda não foi atingido. Para detalhar ainda mais esse quadro, há outros indícios do caráter não-dogmático do platonismo, como a figura multifacetada do filósofo. De fato, Platão descreve o filósofo como alguém sujeito a imperfeições teóricas que lhe exigem reiterados esforços intelectuais; a paixões mundanas (amor, admiração, desconforto psíquico etc.) que devem ser transformadas e dirigidas para fins filosóficos; e - eis o ponto que aqui interessa - como alguém entregue aos ataques de um tipo de ignorância nascida da própria dificuldade de lidar

4. Para a aceitação dessa tese, cf. DONINI; FERRARI, 2012, p. 100-103; SEDLEY, 2004; CHAPELL, 2005. 5. A crítica mais contundente da atualidade é a de Altman (2016), que propõe um paradigma hermenêutico baseado na ordem de leitura e ensino dos Diálogos, não em sua provável data de composição. Confira-se sobre isso minha resenha (ENGLER, 2018). 
com conceitos universais. Não se trata de um ser onisciente que, tendo superado o elemento de incompletude pressuposto no prefixo phil-, torna-se um sophós que conhece a tudo do ponto de vista universal, como o sábio de Aristóteles (Metph. 982a21-22). A despeito de alguns trechos de cunho protréptico exibirem traços de dogmatismo, máxime quando retirados de seu contexto dramático, o conceito de intermediário (metaxý) e de ignorância como errância psíquica (plánē) garantem uma unidade doutrinal em torno da figura do filósofo que descortina panorama assaz diverso, fortemente alheio ao dogmatismo. O escopo deste artigo é explorar brevemente esse tópico.

No que se segue, apresento primeiramente o conceito de intermediário e sua relevância para a concepção platônica de filosofia (seção II), analisando brevemente o Lísis, o Fedro e o Banquete. Esse tema dá a entender que a figura do filósofo dogmático e possuidor de um saber pleno não resiste a uma leitura séria dos Diálogos. Na próxima seção (III), apresento a ideia de que a ignorância se caracteriza por um movimento de errância psíquica e de falta de acordo interno - uma ideia ainda inexplorada pelos comentadores - e que ela acomete o filósofo em diversos estágios de sua pesquisa. Para isso, examino a ocorrência dessa tese no Alcibíades Maior e no Fedro. Trata-se de uma condição ontológica do filósofo, advinda de seu trato com conceitos universais, que sublinha o esforço que ele deve envidar para que, de maneira amiúde temporária e imperfeita, atinja o conhecimento das ideias. Como que de passagem, analiso igualmente o estado oposto da ignorância, isto é, a posse do conhecimento que é descrita como uma situação de acordo (homónoia) e estabilidade. Na seção IV, por fim, mostro como Platão atribui esse andar a esmo a Sócrates, descrevendo o filósofo-mor dos Diálogos como um ser errante e sujeito à ignorância, em acordo com as obras acima mencionadas. Argumento, outrossim, que o mesmo processo determina a natureza da aporia, como se depreende de alguns diálogos. Como há de ser visto, em parte a aporia acontece porque, ao lidar com conceitos universais, os interlocutores de Sócrates são obrigados a abandonar sua limitada perspectiva empírica e aproximar-se das ideias.

\section{METAXÝ: O FLĹSOFO COMO INTERMEDIÁRIO ENTRE O SABER E A IGNORÂNCIA}

O tema do intermediário já adquiriu plena cidadania entre os estudiosos de Platão ${ }^{6}$. Por fazer-se presente em mais de uma obra e não ensejar nenhuma contradição evidente, ele forma unidade doutrinal cerrada que muito facilita sua

6. Karl Albert (1991, p. 55), por exemplo, sustenta que entender o conceito de intermediário é o passo mais fundamental para compreender o conceito platônico de filosofia. O livro de Giovanni Reale 
compreensão. Um de seus tratamentos mais acabados encontra-se no Lisis, onde Sócrates empenha-se em definir o que seria amizade. O intermediário é evocado para que Sócrates e seus interlocutores escapem a duas hipóteses extremas que, ao longo da discussão, se revelam errôneas: o amigo não pode ser amigo do semelhante (homoîon), nem do dessemelhante (enantíon), porque nos dois casos a razão de ser da amizade se perde. No encontro de duas pessoas boas e semelhantes, que possuem gostos, características morais e desejos similares, a amizade se esvai porque nenhum dos dois tem algo que oferecer ao outro; sendo ambos bons e bastando-se a si mesmos, eles não têm motivo para procurar o convívio de outrem (Lys. 214d3-7). O encontro de duas pessoas diferentes, por sua vez, é rejeitado por um arrazoado do senso comum: afinal, como poderia o temperante desfrutar do convívio do intemperante, ou o bom do convívio do mau? Por conseguinte, a amizade é igualmente inviável entre seres dessemelhantes (Lys. 215c2-a6). Deste modo, Sócrates precisa recorrer a uma inspiração divinatória para encontrar a terceira via que há de salvá-los desses extremos e, ao fazê-lo, ele acaba por inovar a psicologia da época, além de introduzir o conceito determinante com o qual Platão descreve o filósofo ${ }^{7}$. No que toca à amizade, essa via é a do intermediário. Os interlocutores percebem que o intermediário - aquele que não é nem completamente bom, nem completamente mau - só principia a amar o que é bom, e tenta depois ser seu amigo, quando é afetado por algum tipo de mal. Antes disso, ele não teria motivos por que buscar a convivência dos bons, dado que já possua em si o bem.

Sócrates. Digo, pois, como que a profetizar, que aquele que é amigo tanto do belo quanto do bom, este não é nem bom nem mau. Escuta, pois, em relação a que coisas falo de forma profética. Parece-me haver como que três gêneros: o bom, o mau e o que não é bom nem mau. Não te parece assim? (Lys. 216d3-7) ${ }^{8}$.

Platão elucida esse fato com uma analogia médica. Assim como uma pessoa sã não tem razões para procurar o bem da medicina, uma pessoa de todo boa não busca a convivência dos bons. Tal como o doente, ela precisa estar temporariamente afetada por uma carência para que busque o bem fora de si. A afetação por um mal, entretanto, não pode pertencer à essência do indivíduo por ela afetado; deve ser

(2000), por sua vez, leva a cabo uma análise minuciosa do Banquete, em que se destaca a questão do intermediário.

7. “A psicologia trivial que em tempos de Platão se esforçava, com pouco êxito, por encontrar uma explicação para a amizade atribuía-a quer à semelhança, quer à atração dos contrários. Elevando-se acima deste campo exterior de simples comparações psicológicas, o Lísis de Platão, em audacioso avanço, descobre o conceito de "primeiro amado" (prōton phílon), que Platão exige e pressupõe como fonte e origem de toda a amizade entre os homens (JAEGER, 2003, p. 719)". Jaeger não comenta aqui o conceito de intermediário; no entanto, ele não só está pressuposto no Lísis, como é parte fundamental da revolução psicológica que o filólogo alemão menciona.

8. Tradução minha. 
algo acidental, como a tintura do cabelo. Ela serve para movê-lo em direção ao bem, se não o tornar completamente mau (Lys. 217a3-217e6).

Sócrates. Logo, quando o mal está presente, sem que ele [o amigo] se torne mau, esta própria presença o faz desejar o bem. Se ela produz o mal, por outro lado, priva-o tanto do desejo quanto da amizade do bem. Porque então não se pode dizer que seja nem mau nem bom, mas apenas mau; e o mau não era amigo do bom (Lys. 217e6-219a2).

Uma vez estabelecido isso, Sócrates aplica a mesma categorização conceitual à posse do conhecimento. Formam-se assim três classes de seres humanos. $\mathrm{Na}$ primeira delas, estão aqueles homens (e também os deuses) que, possuindo o conhecimento, não têm motivos para tornar-se amigos da ciência; eles não carecem de nada e, portanto, não buscam o saber. Na segunda classe, está o outro extremo: as pessoas ignorantes que, de tão afetadas por seu mal, nem ao menos desejam o saber. Elas supõem que possuem o conhecimento e não se sentem incitadas a procurar por nada. Por fim, há a classe das pessoas que assumem posição intermediária: são aquelas que de fato dispõem de algum conhecimento, mas apenas a ponto de perceber o quanto ignoram, e que eo ipso decidem correr atrás da ciência. Reconhecendo que estão tomadas de um mal passageiro, a ignorância, elas envidam esforços para curar-se. Como a palavra sugere, tais são os verdadeiros amigos da sabedoria, os filósofos.

Sócrates. Pelas mesmas razões, pois, podemos dizer que aqueles que já são sábios não filosofam/amam a sabedoria (philosopheîn), quer sejam deuses ou homens. E tampouco filosofam/amam a sabedoria (philosopheîn) aqueles que, tendo sido assim afetados pela ignorância, tornam-se maus. Pois nenhum homem mau ou ignorante ama a sabedoria (philospheîn). Restam assim, por conseguinte, aqueles que têm em si este mal, a ignorância, sem que por causa disso se tornem insensatos e ignorantes, senão que reconhecem não saber as coisas que ignoram. Por isso, filosofam/amam a sabedoria apenas aqueles que não são bons nem maus. Os maus não filosofam/ amam a sabedoria, nem os bons, pois nem o dessemelhante pode ser amigo do dessemelhante, nem o semelhante do semelhante, segundo nos pareceu em nossas discussões recentes. Ou não vos recordais disso? (Lys. 218a2-b5).

Essa é a doutrina platônica sobre o intermediário, tal como exposta no Lísis. Por si só ela sugere que o filósofo não é possuidor de um saber completo e universal, pelo qual poderia ser considerado sábio; ao contrário, sua característica fundamental está em ter consciência do quanto ignora e em tentar livrar-se dessa ignorância através do conhecimento. Noutras palavras, a filosofia só nasce para aqueles que sentem na pele as agruras do erro e da carência de conhecimento; os ignorantes e os sábios desfrutam, ao revés, de uma bem-aventurança que lhes torna inútil a procura pelo saber. Em razão da natureza dramática do Lisis e de seu enquadramento composicional entre os diálogos da juventude, pode-se crer que 
se trata da descrição da figura de Sócrates, cuja profissão de ignorância constitui o fundamento dos diálogos dessa fase. No Fedro, por seu turno, Platão retoma de fugida essa doutrina, quando descreve o tipo de orador que, por dominar os preceitos da dialética, sabe compor aquele gênero de discursos que agrada aos deuses. Seria exagero, pensa ele, chamar tais pessoas de sábias, pois a rigor tal título deveria ser exclusivamente reservado aos deuses; o que lhes cabe bem é o epíteto de "amigos da sabedoria", uma vez que, novamente, eles têm consciência de sua carência.

Sócrates. O nome de sábio, Fedro, a mim me parece ser exagero, pois tal nome convém apenas ao deus; porém, o de amigo da sabedoria (philósophon), ou algo que o valha, lhes é mais adequado e também soa melhor (Phdr. 278d3-6) .

Esse elemento de incompletude, como se sabe, é trabalhado no Banquete. Aqui, a conexão do prefixo phil- com a ideia de desejo e carência é explorada em páginas de insuperável beleza teórica e poética ${ }^{10}$. $\mathrm{O}$ segredo para notar que tal assunto se refere ao conceito de filosofia, ligando-se pois ao Lisis e o Fedro, consiste em perceber que o Amor é um tipo de filósofo. Já de há muito se admite que Platão sublimou a imagem de seu mestre na figura de Eros: enquanto Alcibíades descreve um Sócrates mais real, sem porém descurar de analogias míticas, o mito de Eros retrata um Sócrates idealizado em sua missão de parir os frutos imortais do conhecimento na alma de seus amados. O próprio Sócrates parece autorizar essa comparação, pois reconhece que detém a arte erótica (Thg. 128b5), ainda quando negue a si mesmo a posse de outros saberes. Na conversa com Agatão, que antecede o mito contado por Diotima, Sócrates obriga o anfitrião a admitir que, se o amor ama o que é bom e belo, então o próprio amor é carente dessas coisas, porque ninguém deseja obter aquilo que já possui. O conceito de intermediário assoma pela primeira vez no interior de uma conversa que segue o método de perguntas e respostas típico de Sócrates.

Sócrates: Se portanto o Amor é carente do que é belo, e o que é bom é belo, também do que é bom seria ele carente.

Agatão: Eu não poderia, ó Sócrates, contradizer-te; mas seja assim como tu dizes $(\text { Conv. 201c4-7) })^{11}$.

\footnotetext{
9. Tradução minha.

10. Note-se que, ao enfatizar a ideia de carência no Banquete, Platão desvia-se de um sentido mais costumeiro do verbo phileîn, que denota o hábito ou o trato cotidiano com alguma coisa. Este é o sentido predominante na ideia de que o filósofo é alguém que, por amar a sabedoria, lida diariamente com questões relativas ao saber. Sobre isso, confira-se o estudo filológico de Burkert (1969, p. 172), que mapeia o uso do verbo em autores da tradição pré-filosófica; e o comentário de Albert (1991, p. 54) e Hadot (1999, p. 38).

11. Tradução de José Cavalcante Souza.
} 
No mito de Eros, porém, ele assume contornos ainda mais nítidos. O amor é descrito primeiramente como um ser entre a beleza e a feiura: ele não é completamente belo, porque disso sente carência, mas nem por isso é feio. E surge então como um grande gênio (daímōn) cuja natureza oscila entre o divino e o mortal (metaxý); alguém que não é em si mesmo um deus, porque tem carência de algo, sem que se reduza à simples humanidade. Para Diotima, o amor tem o papel de mediar (en mésō) as relações entre os deuses e os homens. É por meio dele que os seres humanos - através de magias, de súplicas e sacrifícios - fazem seus pedidos aos deuses e recebem suas respostas. Tal como Íris e Hermes, o amor é espécie de hermeneuta que permite que o todo se complete. Ele estabelece grande parte das relações entre essas duas esferas e, embora não tenha um símbolo tão visível quanto o arco-íris, realiza a mesma tarefa de criar um espaço em que dois polos opostos se encontram e comunicam entre $\mathbf{~ s i}^{12}$. Aliás, segundo Diotima, ele não é o único gênio que existe, pois muitos outros há que também mediam o convívio entre os deuses e os homens. As pessoas que são entendidas nessas coisas - os filósofos como Sócrates - são ditos homens de gênio (daimónios), ao passo que os demais, sábios em outros ofícios especializados, são os meros artesãos.

\footnotetext{
Diotima: Como nos casos anteriores - disse-me ela - algo entre mortal e imortal. Sócrates: O quê, então, ó Diotima?

Diotima: Um grande gênio, ó Sócrates; e com efeito, tudo o que é gênio está entre um deus e um mortal.

Sócrates: E com que poder? perguntei-lhe.

Diotima: O de interpretar e transmitir aos deuses o que vem dos homens, e aos homens o que vem dos deuses, de uns as súplicas e os sacrifícios, e dos outros as ordens e as recompensas pelos sacrifícios; e como ele está no meio de ambos ele os completa, de modo que o todo ficado ligado todo ele a si mesmo. Por seu intermédio é que procede não só toda a arte divinatória, como também a dos sacerdotes que se ocupam dos sacrifícios das iniciações e dos encantamentos e enfim de toda a adivinhação e magia. Um deus com um homem não se mistura, mas é através desse ser que se faz todo o convívio e diálogo dos homens com os deuses, tanto quando despertos como quando dormindo; e aquele que em tais questões é sábio é um homem de gênio, enquanto o sábio em qualquer outra coisa, arte ou ofício, é um artesão. E esses gênios, é certo, são muitos e diversos, e um deles é justamente o Amor (Conv. 202d11-203a8).
}

Maravilhado ante a exposição da sacerdotisa, Sócrates pergunta qual seria a origem do Amor. Diotima conta então o mito do nascimento de Eros. Segundo ela, Eros é fruto do conúbio entre Recurso (Póros) e Pobreza (Penía). Seu nascimento se deve a uma artimanha de sua mãe, que superou seu pai em engenho e astúcia. Ele nasceu com natureza dúbia e agrega apanágios de ambos os progenitores. Pelo lado da mãe, é duro, seco, vive sem lar, descalço, pobre e em constante necessidade; oferece-nos a imagem de um homem simples que, como Sócrates e Aristodemo, não

12. Cf. JAEGER, 2003, p. 736; ROSEN, 1987, p. 198. 
possui condições para calçar-se direito. Pelo lado do pai, inversamente, é ele um ser insidioso para com as coisas belas, corajoso, viril e decidido; é caçador denodado, ávido de sabedoria e cheio de artimanhas; passa toda a vida a filosofar e é terrível mago, feiticeiro e sofista. Nesse trecho nota-se claramente o jogo com a etimologia da palavra Póros, usada para denominar o pai de Eros. Platão afirma que o Amor não é mortal nem imortal, mas germina todos os dias, quando está provido de recursos (euporésê), e às vezes acontece-lhe de morrer para depois retornar à vida, em razão da natureza paterna. Ele nunca enriquece nem fica completamente sem recursos (aporeî); sempre consegue (porizómenon) alguma coisa, embora ela se lhe escape em seguida. Por tudo isso, ele está a meio caminho entre o saber e a ignorância. Esta é a razão pela qual ele filosofa.

\begin{abstract}
Diotima: Nenhum deus filosofa (philosopheî) ou deseja ser sábio - pois já é - , assim como se alguém mais é sábio, não filosofa. Nem também os ignorantes filosofam ou desejam ser sábios; pois é nisso mesmo que está o difícil da ignorância, no pensar, quem não é um homem distinto e gentil, nem inteligente, que lhe basta assim. Não deseja portanto quem não imagina ser deficiente naquilo que não pensa lhe ser preciso (Conv. 204a1-7).
\end{abstract}

Definida a natureza do amor, pode-se deduzir que ele é também filósofo. $\mathrm{O}$ forte do argumento reside na mesma estrutura triádica usada acima, pela qual existem dois extremos e um intermediário que absorve parcialmente os atributos de cada um. Como se vê a partir do Lisis e do Fedro, por conseguinte, essa descrição do filósofo possui coerência doutrinal e aplica-se a outros diálogos, especialmente àqueles em que Sócrates é pintado como o filósofo por excelência. Para os propósitos do presente artigo, ela deixa claro que não se pode conceber o filósofo platônico como alguém dogmático e detentor de um saber pleno. Pelo contrário, sua superioridade em relação às pessoas comuns consiste precisamente no reconhecimento de sua ignorância, dado que, por uma questão de humildade, ele tampouco ousa comparar-se à posição privilegiada dos deuses. O que significa tal ignorância e o que ela implica, pois, é tema da próxima seção.

\title{
3. IGNORÂNCIA COMO ERRÂNCIA E FALTA DE ACORDO PSÍQUICO
}

Assim como Platão se esforça por definir a sabedoria, ele possui pensamentos precisos sobre a ignorância. Seu papel é crucial de um ponto de vista educacional e antropológico. No primeiro caso, ela constitui um dos fundamentos do aprisionamento dos cavernícolas (cf. Rep. 514a1-2, apaideusías) e sua eliminação está na base, portanto, de toda a pedagogia filosófica de Platão. No segundo, ela serve 
para definir o humano em relação ao divino, como comentado acima. No Sofista, Platão atesta a centralidade desse problema. Ao discorrer sobre a mais genuína definição do sofista, a que se aplica a Sócrates, ele põe em estreita relação a refutação e a ignorância. A ignorância pertence aos vícios da alma: enquanto a injustiça, a intemperança e a covardia são definidas como enfermidades da alma, a ignorância, classificada como uma afecção (páthos) múltipla e variegada, é considerada uma fealdade.

Teeteto: Sim, é preciso admitir ainda que há dois gêneros de vício na alma: a covardia, a intemperança e a injustiça devem todas ser consideradas como uma enfermidade em nós; e nesta afecção (páthos) múltipla e diversa que é a ignorância (agnoías), devemos ver uma fealdade (aískhos) (Soph. 228e1-5) ${ }^{13}$.

O papel do sofista enquanto refutador irônico consiste em purgar a alma de seu interlocutor dessas doenças, tal como o médico purga o corpo de seus pacientes. Mais para frente comentarei esse processo. Por ora, basta enfatizar como se trata de algo imprescindível. Segundo Platão, de tal maneira a ignorância nos afeta, que sequer o Rei da Pérsia poderia ser feliz, estivesse ele acometido por semelhante fealdade (Soph. 230d6-e3). Ou seja, o objetivo central do trabalho de Sócrates reside na tentativa de livrar a si e a seus interlocutores da ignorância. Se isso é dito ipsis litteris no Sofista, além de estar pressuposto na alegoria da caverna, não fica claro, porém, o que seria propriamente a ignorância. Apenas três pontos são enfatizados: que a) a ignorância se trata de um grande mal, talvez o maior de todos; que b) enfeia nossa alma; e que sua c) natureza é similar à de uma paixão (páthos). É no Alcibíades Maior que Platão oferece análise mais acurada da ignorância.

Nesta conversa de Sócrates com seu dileto pupilo - trata-se da primeira conversa entre ambos - o filósofo precisa convencer um jovem ambicioso e de grandes dotes intelectuais de que ele deve educar-se e cuidar de sua alma, se deseja dedicar-se à política de forma virtuosa e tornar-se o maior dos gregos. $\mathrm{O}$ primeiro passo para que isso ocorra, conforme o tom dos diálogos menores, consiste em levar Alcibíades a cair em aporia e reconhecer humildemente sua ignorância. Sócrates consegue esse feito sem muita dificuldade. Depois de discutir o justo e o belo, ocasião em que refuta as doutrinas sofísticas a que Alcibíades estava acostumado, o jovem exclama: "Mas pelos deuses, Sócrates, eu mesmo não sei nem o que digo, e as coisas parecem completamente absurdas (atópōs) para mim. Enquanto vais perguntando, ora me parecem de um jeito, ora de outro (Alc. I. 116e-2-4) $)^{14 \prime}$. Mais para frente, então, vem o diagnóstico de Sócrates:

13. Tradução de Jorge Paleikat e João Cruz Costa.

14. Tradução minha. 
Sócrates. Puxa vida, Alcibíades, como experimentas [tal] experiência (páthos péponthas)! Eu mesmo não me atrevo a nomeá-la, mas, uma vez que estamos a sós, cumpre dizê-lo. Convives com a mais extrema ignorância (amathía), meu querido, de modo que o raciocínio [acima] acusa a ti mesmo; pois te arrojas à política antes que te tenhas educado. Não é apenas tu que experimentas (péponthas) isso, porém muitos dos que se ocupam dos assuntos da cidade, com exceção de poucos, quiçá de teu tutor, Péricles (Alc. I. 118b4-118c2).

Antes de fazer com que Alcibíades admita sua ignorância, porém, Sócrates lhe explica o que lhe ocorre no sentimento de aporia. Tudo aquilo em que Alcibíades se fiara, e sobre o que se baseava a opinião corrente de Atenas, fortalecida pelas teses sofisticas, começa a ruir ante seus olhos e ele se sente "estranho"; as ideias como que se movem em sua frente e ora lhe parecem de um modo, ora de outro. Sócrates diz a Alcibíades que, caso alguém lhe perguntasse quantas mãos possui, não hesitaria ele em responder que são duas, pois tem conhecimento seguro sobre isso. Alcibíades concorda com o exemplo, mas com algum receio, a tal ponto e intensidade chega a sua desorientação (Alc. I. 116e7-117a2). Contudo, quando alguém lhe pergunta alguma coisa que desconhece, como o conceito de justiça, Alcibíades vê-se obrigado a responder de forma contraditória e ainda contra a própria vontade, vagueando desordenadamente de um lado para outro. Sócrates conclui, portanto, que a nossa alma torna-se errante (planâsthai), sem saber que respostas dar, quando se debruça sobre aquilo que julgamos saber, mas que na realidade não sabemos; ela cessa de vaguear quando somos conhecedores do assunto.

Sócrates. Então é evidente que tu, contra a tua vontade, respondes contraditoriamente sobre as coisas que não sabes.

Alcibiades. É verossímil.

S. Mas não dizes que vagueias (planâsthai) em tuas perguntas sobre o justo e o injusto, o belo e o feio, sobre o mau e o bom, sobre o conveniente e o inconveniente? Se tu vagueias (planâ), pois, não é decerto porque nada sabes acerca desses assuntos?

A. Assim me parece.

S. Porventura não é assim que se comportam as coisas, portanto: quando alguém não sabe algo, necessariamente sua alma há de vaguear (planâsthai) acerca disso?

A. Claro que sim (Alc. I. 117a3-b3).

A ignorância, por conseguinte, engendra a volubilidade de opiniões e nos faz pensar ora de um modo, ora de outro. O mais relevante a acentuar aqui é que ela diz respeito primordialmente àqueles conceitos gerais que são objeto da filosofia. Como visto, Sócrates enumera vários temas recorrentes nos Diálogos: bom e o mau, o justo e o injusto, o belo e o feio. Quando se trata de questões óbvias, como a quantidade de olhos que temos, não há espaço para a errância. Em contraposição a isso, o conhecimento (epistếmē) já fora definido como certa estabilidade ou consenso verbal e psíquico (homónoia), tal como ocorre com as pessoas que usam os substantivos da 
língua grega para designar corretamente os objetos a que se aplicam. Essas pessoas não discordam entre si, nem em seu íntimo.

Sócrates. E não é verdade que os que sabem concordam (homologeîn) entre si e não diferem [entre si]?

Alcibiades. Sim.

S. Se diferirem a respeito de algo, tu acaso dirás que o sabem?

A. Não, com certeza.

S. Como, pois, poderiam ser mestres disso?

A. De nenhuma maneira.

S. Ora, vejamos. Acaso te parece que haja desacordo entre as pessoas a respeito do que seja uma pedra ou um pedaço de lenha? E a quem quer que o perguntes, não se mostrará de acordo (homologoûsin) sobre as mesmas coisas e não se moverá em direção a elas quando quiser pegar uma pedra ou um pedaço de lenha? Assim se dá com coisas similares. Logo, compreendo que é isto o que chamas saber grego, não? S. Sim (Alc. I. 111b3-c5).

Todavia, o mesmo não se dá quando estão em jogo conceitos gerais. Platão já insistira sobre esse ponto na discussão sobre o justo e o injusto, discussão que conduz Alcibíades ao estado aporético. Ele argumenta que as guerras e demais inimizades entre cidades - como o caso de Troia - nascem do fato de que as cidades diferem entre si acerca do justo e injusto. Sem entrar em acordo sobre isso - e aqui Platão emprega o sentido político do termo homónoia (consenso), depois usado pela sofística, que se contrapõe à stásis (dissenso) - elas resolvem nas armas suas diferenças (Alc. I. 112a10-112d2). Isso prova que tais pessoas não podem ensinar o que é o justo e o injusto, pois estão em desacordo entre si; e, no que se refere a Alcibíades, prova que ele desconhece esses conceitos, haja vista sua alma se ponha a andar a esmo e a dar respostas contraditórias quando interrogada. "Sócrates. Como, pois, pode ser verossímil que saibas o que é o justo e o injusto, sobre coisas em que erras (planâ) assim, se o não aprendeste de alguém, nem o descobriste por conta própria (Alc. I. 112d7-9)?

Além disso, Sócrates e Alcibíades percebem outro fato deveras significativo, qual seja, que a nossa alma não se torna errante quando voltada para aquilo que não supomos saber, isto é, aquilo que estamos certos de ignorar e sobre o que não aventamos nenhuma conjectura. Por exemplo, não vagueia nossa alma sobre como se deve escalar o céu, uma vez que admitimos de antemão não saber como isso é possível.

Sócrates. E acaso sabes de que modo se pode escalar o céu?

Alcibíades. Por Zeus, eu não!

S. E acaso também erra (planâtai) a tua opinião acerca disso?

A. Não, com certeza.

S. Sabes tu a causa disso, ou devo eu explicá-la?

A. Explica-a. 
S. Pois bem, meu caro: é que não julgas saber o que de fato não sabes (Alc. I. 117b512).

Mais do que isso, tampouco vagueia nossa alma quando, cônscios de nossa ignorância, entregamos a decisão àqueles que efetivamente sabem: ao navegar, não ficamos a supor como usar o timão, senão que delegamos tal tarefa ao piloto e ficamos tranquilos (Alc. I. 117c9-d6). Os erros na conduta prática nascem dessa mesma ignorância. Tentamos levar a cabo ações sobre coisas que supomos conhecer e acabamos nos enganando; quando estamos seguros de desconhecê-las, em contrapartida, deixamo-las para os que as conhecem e não sofremos prejuízos. Por conseguinte, os erros só prejudicam aqueles que se julgam sábios sem que o sejam: os "verdadeiros" ignorantes passam a vida entregues à opinião alheia e não se arvoram um saber que não possuem, ao passo que os sábios jamais se equivocam. Em verdade, este tipo de ignorância é precisamente a causa dos nossos males e ela é tanto mais daninha e vergonhosa quando se refere a coisas importantes (tà mégista), como o belo, o útil, o justo etc. (Alc. I. 117d6-118a5). Ou seja, neste breve diálogo Platão já correlaciona o conhecimento de conceitos gerais com nossas escolhas práticas, correlação essa que está no cerne da reflexão ética em suas obras maduras.

A ligação da ignorância com os conceitos gerais possui, outrossim, aspectos retóricos. No Fedro, Platão retoma essa doutrina rapidamente ao explicar o campo de assuntos sobre o qual a retórica versa. A retórica não trata de coisas que são conhecidas de todos e cuja definição já está dada, segundo ele, mas daquelas coisas mais gerais, como o que seria o bom, o justo ou o amor, sobre as quais não há consenso definitivo. A maior volubilidade conceitual de tais assuntos permite que $o$ orador exerça toda a potência de sua arte, que consiste em fazer com que os ouvintes "vagueiem" junto com o discurso. Na ocasião, Platão utiliza novamente um exemplo baseado no conhecimento dos nomes comuns: todos sabemos como usar os termos "ferro" e "prata", e por esse motivo é mais difícil compor uma peça retórica sobre isso. Já os temas sobre os quais estamos em desacordo, como o "justo", adaptam-se a contento aos fins da retórica. Desse modo, o orador deve não apenas conhecer o caráter das pessoas a que se dirige (polytropía), como também os assuntos sobre os quais nossa alma se torna errante.

Sócrates. Porventura não é claro para todos que em algumas questões estamos de acordo (homonoêtikōs), ao passo que em outras divergimos (stasiōtikōs)?

Fedro. Parece que compreendo o que dizes; mas expressa-te com clareza ainda maior. S. Quando alguém menciona o nome do ferro ou da prata, acaso não o compreendemos todos?

F. Com certeza.

S. E o que ocorre quando se trata do justo e do bom? Não vai cada um para um lado e não ficamos em descordo (amphisbētoumen) uns com os outros e até mesmo em nosso íntimo? 

F. De fato.
S. Em algumas questões, portanto, estamos de acordo, em outras, não.
F. É assim.
S. E em qual delas estamos mais propensos ao engano (euapatētóroi), e em quais a retórica age de forma mais vigorosa?
F. É claro que naquelas em que erramos/vagueamos (planốmetha).
S. Aquele que intenta adquirir a arte da retórica, portanto, deve primeiramente ter feito uma divisão metódica dessas coisas, e ter também selecionado quais características de cada gênero: naquele em que a multidão erra/vagueia (planâsthai), e naquele em que não o faz (Phdr. 263a2-b9).

Esse pensamento se relaciona com a definição de retórica dada no diálogo, a saber, um "leve deslocamento do sentido das palavras" (Phdr. 262a2-3), assim como com a importante noção de ilusão/engano (apátē) (Phdr. 261e6-7). Ele mostra que o convencimento da retórica arrima-se em parte na ignorância do ouvinte e na capacidade que o orador possui de explorar determinados temas sobre os quais não há concordância tácita ${ }^{15}$. Dado que esses temas sejam igualmente próprios da filosofia, vê-se por que Platão propõe como modelo ideal de retórica um tipo de dialética similar à empregada nos Diálogos.

Para os presentes propósitos, importa frisar que, à parte as possíveis ligações entre o orador e o filósofo, a menção da errância em associação com os conceitos gerais e a utilização de um exemplo que recorda claramente o Alcibíades Maior revelam a unidade de pensamento que Platão tinha sobre esse tópico. É também significativo que tal aconteça no Fedro, um diálogo que se refere ao intermediário; assim, a relação entre errância psíquica do filósofo e sua posição ontológica intermediária a respeito do saber fica ainda mais clara.

\section{CASOS DE ERRÂNCIA: SÓCRATES E EUTÍFRON}

Se o filósofo ocupa posição ontológica intermediária entre a ignorância e o saber, e se a ignorância consiste em um desacordo consigo mesmo e um movimento de errância psíquica, segue-se daí que tanto Sócrates, o filósofo no superlativo, quanto as personagens que passam pela purificação do filósofo, começando assim a filosofar, devam apresentar tais sintomas. Testemunham sobre o primeiro caso Hipias Menor, o Hipias Maior, a Apologia e o Eutífron, sem falar que o Fédon alude 15. Este é outro ponto em que Platão parece recuperar algo da doutrina de Górgias, como o faz claramente na Apologia em relação à Defesa de Palamedes. O conceito mais fundamental que ele toma do sofista é o conceito de ilusão (apátē) ( $P h d r$. 261e6-7); porém, ao relacionar a retórica à errância psíquica, ele parece deambular em torno de outra ideia de Górgias, qual seja, de que a ilusão da opinião (dóxēs apatếmata) é intrínseca à alma humana (Hel. 10). Nos dois casos, trata-se de um diagnóstico da persuasão retórica que faz referência explícita à constituição psíquica dos ouvintes. Sobre essa questão em Górgias e sua possível influência sobre Platão, especialmente no que se refere à diferença entre verdade e opinião, confira-se o estudo insuperável de Seagal (1962, p. 114). 
a algo parecido. Sobre o segundo, embora outros diálogos também o atestem, o Eutifron presta-se novamente como bom exemplo, além do explícito relato do Sofista.

No Hipias Menor, Sócrates explica a seu interlocutor as razões pelas quais não para de importuná-lo com suas dúvidas. Na ânsia de aprender com aqueles que sabem, ele se revela um discípulo perspicaz, porém atacado de grande ignorância, já que sempre diverge de seus mestres.

Sócrates. Vês, Hípias, como tenho razão de dizer que sou tenaz quando me ponho a interrogar os sábios? Pode bem dar-se que seja esse meu único merecimento; de tudo o mais sou muito parcamente dotado, pois sempre me escapa o sentido íntimo das coisas, continuando eu sem saber nada. A melhor prova disso está no fato de, sempre que me ponho a conversar com alguma pessoa de reconhecido mérito e de cuja sabedoria os helenos dão testemunho, torna-se manifesto que eu nada sei. Não há questão, por assim dizer, em que estejamos de acordo. E que maior prova de ignorância poderá haver do que discordarmos dos sábios? Porém uma qualidade maravilhosa me salva: não me envergonho de aprender, mas questiono e interrogo, e fico muito obrigado aos que me respondem, sem jamais regatear-lhes agradecimento. Quando aprendo algo, nunca nego minha dívida com fazer passar como achado próprio o que tivesse aprendido com outrem; pelo contrário: mimoseio a quem me ensina com o nome de sábio e declaro abertamente o que aprendi com ele (Hip. Mi. 372a6-c8) ${ }^{16}$.

Isso se repete na discussão com Hípias. Sócrates discorda do sofista e sustenta a tese contrária; ele sabe, contudo, que essa discordância advém de sua natureza afeita aos estados aporéticos. E sua conclusão é que, quando vacila/erra (planōmai) sobre uma questão, tal se dá porque ele nada sabe.

É o que se dá agora conosco, porque não posso concordar com o que dizes; discordo em toda a linha. Sei perfeitamente que é minha culpa, por ser quem eu sou, para não me referir a mim mesmo em termos mais elevados. A mim me parece, meu caro Hípias, precisamente o oposto do que dizes. O que eu acho é que os que causam mal aos outros, ou cometem injustiça, mentem ou enganam de caso pensado, não involuntariamente, são melhores do que os que o fazem sem querer. Por vezes, contudo, penso de modo contrário e me ponho a vacilar/errar (planōmai) sobre o assunto, o que prova que o desconheço (mè eidénai) (Hip. Mi. 372c8-e1).

Ou seja, Platão reitera a ideia de que a errância psíquica nasce da ignorância. O texto constitui um dos mais explícitos relatos da profissão de ignorância socrática e a palavra plánē deve ser vista como uma alusão ao Alcibíades Maior, haja vista a proximidade temática e composicional de ambos os diálogos. Mais do que isso, em seguida ele traz à tona outro tema que pertence à tópica da ignorância e que reaparece no Sofista: a ideia de que o sábio pode curar o ignorante, tal como o médico cura o doente, porquanto a ignorância esteja para a alma assim como a doença está para o corpo.

16. Tradução de Carlos Alberto Nunes. 
Agora, por exemplo, encontro-me em fase de certa perturbação (katēbolè: literalmente, desmaio) que me leva a considerar as pessoas que cometem qualquer erro de caso pensado melhores do que as que o fazem involuntariamente. Atribuo o mal de agora a nossa conversação anterior, causa de eu julgar neste momento que os que praticam o mal sem o querer são piores do que os que assim procedem de caso pensado. Usa, portanto, de condescendência para comigo e não te recuses a curar-me a alma. Muito maior benefício me prestarás livrando minha alma de sua ignorância do que se me curasses de uma doença do corpo [...] (Hip. Mi. 372e1-373a1).

No final do diálogo, o tema da ignorância e sua ligação com o sentimento de andar a esmo são novamente evocados. Pela insistência de Platão nessa questão e seu uso abundante de termos correlatos, pois, fica justificada a remissão ao Alcibíades Maior. Na verdade, é somente a leitura conjunta desse último diálogo que vai mostrar a diferença entre os dois tipos de errância que aparecem na passagem: a de Sócrates, que vagueia porque reconhece que não sabe e tenta a todo custo aprender; e a de Hípias, que vagueia por supor saber aquilo que de fato desconhece. O leitor que tiver o Alcibíades Maior em mente poderá fazer essa conexão.

Sócrates. Nem eu, Hípias, a mim mesmo; mas é o que necessariamente se conclui do nosso raciocínio. Porém como te dizia há pouco, nesses assuntos eu vivo sempre a oscilar (planōmai) para cima e para baixo, sem deter-me nunca numa opinião segura. Não é de admirar, porém, que eu e as demais pessoas indoutas andemos assim a esmo (planâsthai). Mas se vós outros, os sábios, também vos mostrais errantes (planêsesthe), isso é que é terrível para todos, pois nem com nos aproximarmos de vós poremos remate a nossas divagações (plánes) (Hip. Mi. 376b8-c6).

No Hípias Maior, Sócrates dá a mesma justificativa ao sofista. Diante das reprimendas de Hípias, que censura o fato de Sócrates entregar-se a questões absurdas e de pouca monta, ao invés de dedicar-se a compor belos discursos públicos, o filósofo responde que não tem certeza nenhuma e vive sempre a vaguear e a cair em aporia. Ele confirma o sentido mais técnico do termo plánē e revela como, nesta fase do pensamento de Platão, se trata de conceito fulcral.

\begin{abstract}
Meu caro Hípias, és, realmente, bem-aventurado, tanto por saberes em que os homens devem aplicar-se como por te haveres esforçado neste sentido, conforme declaraste. Eu, pelo contrário, como parece, caí nas malhas de um destino adverso, que me leva a errar sem pausa (planōmai) e em perpétua incerteza (aporō aei), e quando a vós outros confesso, por serdes sábios, minhas dificuldades (aporian), vejome maltratado por expressões rudes, mal acabei de falar (Hip. Mai. 304b7-c4) ${ }^{17}$.
\end{abstract}

NoEutifron, por sua vez, Sócrates também admite que a aporia e a consequente errância psíquica que ele causa em seu interlocutor são efeitos que ele mesmo sente. Embora a palavra plánē e seus correlatos não sejam empregados, a ideia de

17. Tradução de Carlos Alberto Nunes. 
movimento e de vaguear psiquicamente, ficando em desacordo sobre coisas dantes consideradas óbvias, é patente na metáfora das estátuas errantes. Note-se que, de mais a mais, a discussão sobre a essência da piedade não versa sobre nenhum tema amplamente conhecido, como o uso da palavra "ferro" ou "prata". O tema é apenas conhecido (supostamente) por Eutífron, e por isso ele sente a aporia de modo mais agudo; todavia, ele é um conceito geral se enquadra assim entre os temas que têm a propensão de gerar desacordo, segundo o Alcibíades Maior e o Fedro.

Eutífron: Eu já não sei dizer-te o que penso, Sócrates. Pois parece que tudo gira ao nosso redor sem encontrar um lugar fixo.

Sócrates: O que dizes, Eutífron, parece ser trabalho do nosso antepassado Dédalo. E se fosse eu que falasse e trouxesse à baila esses motivos, talvez pudesse afirmar, em tom de zombaria, que, por ser descendente daquele, as figuras que apresento em palavras procuram fugir e não querem ficar no lugar que se lhes indica. Porém como neste caso as hipóteses são tuas, convém que procuremos outro motivo de gracejo, porque está claro que não querem ficar contigo, conforme afirmas.

Eutifron. Quer me parecer, Sócrates, que esta galhofa está bem de acordo com o que dissemos. Porque não sou somente eu que inspiro a necessidade de que estas hipóteses girem à nossa volta e se conservem fixas. És tu que me pareces Dédalo, já que, se as coisas dependessem de mim, eu faria de tudo para que ficassem $(\text { Ethph.11b6-c6) })^{18}$.

O significativo sobre essa cena é que ela atribui tal errância a Sócrates, provando que o filósofo está igualmente entregue à ignorância e à aporia. Logo em seguida, este ponto é outra vez ressaltado.

Sócrates: Então, meu estimado amigo, pode ser que seja eu ainda mais hábil do que esse homem em sua arte, visto que ele apenas conseguia que não se conservassem em suas obras, enquanto eu consigo isto não apenas em relação às minhas, mas também às demais. E, com certeza, o que existe de mais extraordinário em minha arte é que sou hábil nela, contra a minha própria vontade. Pois eu só desejaria que minhas razões possuíssem solidez e se mostrassem firmes e isto, em maior grau que os tesouros de Tântalo e a sabedoria de Dédalo juntos (Ethph. 11d3-e1).

Na Apologia, esse fato vem confirmado pelo uso explícito da palavra plánē. Ao narrar sua história, Sócrates descreve aquilo que ele chama de sua errância. Primeiro, ele ouviu do oráculo que era o homem mais sábio. Isso o deixou perplexo e ele decidiu testar a palavra oracular visitando os homens que a opinião pública tinha na conta de sábios. A palavra plánē poderia ser entendia aqui como peregrinação - "vaivéns" é a opção do tradutor Jaime Bruna -, isto é, como o fato físico de que Sócrates se deslocou até cada um dos especialistas da época. Entretanto, os diálogos acima e o fato de que Sócrates cai em aporia (épóroun) ante o pronunciamento do oráculo ( $A p$. 21b7) sugerem, ao contrário, que se trata de emprego técnico do

18. Tradução de Enrico Corvisieri. 
conceito que define a ignorância ou de uma remissão aos diálogos que antecedem a Apologia. Nesse emprego, a propósito, o termo errância é mais adequado porque conserva a ambiguidade da língua grega, que descreve simultaneamente um deslocamento físico e um erro de raciocínio ${ }^{19}$. Ou seja, Platão mostra outra vez que seu mestre reconheceu que ignorava várias coisas e decidiu curar-se de tal mal, isto é, que ele ocupava a posição intermediária acima discutida. Desnecessário dizer que, ao declarar abertamente que se impressionou com a ignorância dos que eram considerados sábios pela opinião pública, Sócrates revela aqui quão irônica era sua declaração no Hípias Menor.

\begin{abstract}
Depois disso, não parei, embora sentisse, com mágoas e apreensões, que me ia tornando odiado; não obstante, parecia-me imperioso dar a máxima importância ao serviço do deus. Cumpria-me, portanto, para averiguar o sentido do oráculo, ir ter com todos os que passavam por senhores de algum saber. Pelo Cão, Atenienses! Já que vos devo a verdade, juro que se deu comigo mais ou menos isto: investigando de acordo com o deus, achei que que os mais reputados pouco faltava para serem os mais desprovidos, enquanto outros, tidos como inferiores, eram os que mais visos tinham de ser homens de senso. Devo narrar-vos os meus vaivéns (tè̀n emè̀n plánēn) nessa faina de averiguar o oráculo (Ap. 21e2-22a 8$)^{20}$.
\end{abstract}

Em uma das histórias autobiográficas do Fédon, a ignorância, a perplexidade e admiração de Sócrates ante as doutrinas naturalistas e a natureza da matemática são amiúde evocadas (Phdn. 96e6-97b4). Aqui Platão não utiliza a palavra plánē, como no Eutifron, porém não parece precipitado concluir que ele descreve o mesmo fenômeno. A história relata o percurso de Sócrates depois do que aconteceu na Apologia $^{21}$. O filósofo não se decepcionou apenas com as pessoas que a opinião pública havia por sábias; até mesmo as explicações naturalistas e as questões matemáticas mais simples lhe pareceram problemáticas, razão pela qual ele continuou a vaguear até decidir-se por empreender a segunda navegação e, como consequência, estudar os discurso/conceitos (lógous). Seria errôneo pensar, porém, que essa guinada lhe abriu as portas da verdade; no reino dos conceitos também impera, como dito, indeterminação e errância, pelo menos até que as ideias sejam atingidas.

19. A palavra plánē e seus correlatos traduzem a ideia de errância, desvio, movimento a esmo, digressão, erro etc. (in errorem induco, decipio, vagor, fallor, fluctuo, digressio). Esses sentidos concretos encontram-se já na tradição pré-filosófica. Em Parmênides, quando o filósofo fala do caminho da opinião, o verbo é usado para denotar um erro de pensamento (B50-DK). Este sentido ganha impulso com Platão e passa a acompanhar a ideia de aporia e ignorância, como assinalado acima na passagem do Hípias Maior. Parece que depois dele estabelece-se o sentido mais intelectualizado do termo, como se pode ver em Aristóteles (Eth. Nic. 1094b16).

20. Tradução de Jaime Bruna.

21. No que tange ao Fédon, pois, seria mais adequado falar em uma das duas histórias autobiográficas do diálogo. Os comentadores têm sido assíduos na omissão da segunda história, aquela que trata da relação de Sócrates com os sonhos proféticos e, especialmente, com a poesia filosófica e popular. Sobre isso, confira-se: ENGLER, 2016. 
Por fim, a confirmação desse efeito de Sócrates é dada no Sofista. Este diálogo possui já estreitas conexões com o Alcibiades Maior pelo fato de discutir o que seria a ignorância e de defini-la com recurso ao mesmo conceito; em ambos os diálogos a ignorância é um páthos. Mas na descrição do refutador irônico há uma alusão explícita à ignorância como errância psíquica e sua relação com a aporia. A errância é atribuída às opiniões contraditórias que Sócrates desenterra de seu interlocutor, o qual reconhece que nada sabe e, a princípio, fica desconte consigo mesmo. No final de todo o processo, entretanto, quando já foi purificado de suas falsas opiniões, ele chega a um estado intermediário, pois acredita agora apenas no que sabe, e em nada além disso. Ou seja, da classe dos ignorantes ele passa para a classe dos que têm consciência que ignoram. A ideia de que o filósofo é espécie de médico que cura a alma do ignorante - também explorada no Cármides - já aparece no Hípias Menor, como discutido acima.

Estrangeiro: Propõem, ao seu interlocutor, questões às quais acreditando responder algo valioso, ele não responde nada de valor; depois, verificando facilmente a vaidade de opiniões tão errantes (planōménōn), eles as aproximam em sua crítica, confrontando umas com outras, e por meio desse confronto demonstram que a propósito do mesmo objeto, sob os mesmos pontos de vista, e nas mesmas relações, elas são mutuamente contraditórias. Ao percebê-lo, os interlocutores experimentam um descontentamento para consigo mesmos, e disposições mais conciliatórias para com outrem. Por este tratamento, tudo o que havia neles de opiniões orgulhosas e frágeis lhes é arrebatado, ablação em que o ouvinte encontra o maior encanto e, o paciente, o proveito mais duradouro. Há, em verdade, um princípio, meu jovem amigo, que inspira aqueles que praticam este método purgativo; o mesmo que diz, ao médico do corpo, que da alimentação que se lhe dá não poderia o corpo tirar qualquer proveito enquanto os obstáculos internos não fossem removidos. A propósito da alma formaram o mesmo conceito: ela não alcançará, do que se lhe possa ingerir de ciência, benefício algum, até que se tenha submetido à refutação e que por esta refutação, causando-lhe vergonha de si mesma, se tenha desembaraçado das opiniões que cerram as vias de ensino e que se tenha levado ao estado de manifesta pureza e a acreditar saber justamente o que ela sabe, mas nada além (Soph. 230b4d4).

Dado que se aceite comumente a composição e o enquadramento dramático tardio do Sofista, é razoável sustentar que a doutrina da ignorância como errância psíquica não é válida apenas para os diálogos menores, senão que persiste ao longo da obra platônica. Sua ligação com a aporia e os conceitos gerais dá a entender que a primeira é fruto do contato com os últimos. Dito de outra forma, Sócrates eleva seus interlocutores a um estado em que, deixando de lado a segurança ofertada pelo sentido comum das palavras, eles se deparam com conceitos que precisam ser estudados e definidos a cada vez. Trata-se da posição intermediária ocupada pelo filósofo, na qual se reflete a consciência da ignorância e o desejo de curar-se dela. Mais do que isso, em razão da proximidade com os conceitos próprios da filosofia, 
trata-se de uma posição mais distante da sensibilidade e mais próxima do inteligível. Nesta ascensão, retratada miticamente na alegoria da caverna e, de forma concreta, em vários diálogos menores, consiste precisamente o início da filosofia.

\section{CONCLUSÃO}

Do que ficou exposto pode-se concluir que a concepção de um Platão dogmático não se sustenta de todo, porquanto ele conceba o filósofo como um ser atacado continuamente pela ignorância. Por muito que se atribua à ironia de Sócrates, ainda parece precipitado tomar por dogmático um pensador que, como Platão, escolheu como seu ideal de filósofo alguém que professava abertamente sua carência de conhecimento. Se o dogmatismo se define pela posse de um saber pleno, então o filósofo platônico não é dogmático, já que deve reconquistar seu saber em um processo contínuo. Naturalmente, quando ele o alcança, é agraciado com a visão maravilhosa de uma ideia isenta de falhas; mas isso é apenas o estágio final de um longo e penoso processo, em que ele deixa sua posição ontológica intermediária e alcança, ainda que por instantes, a posição própria dos deuses ${ }^{22}$. Conquanto a errância psíquica deva então cessar nesse momento final, ela é imprescindível para que os interlocutores abandonem sua limitada perspectiva intelectual e aproximem-se daquele lugar inteligível (Rep. 517b6, noētòn tópon) visado pelo filósofo ${ }^{23}$. No Fédon, essa conclusão se liga à insatisfação com as explicações empíricas e à posse das ideias. No interior da discussão sobre a diferença entre visível e invisível, empírico e ideal, Platão utiliza o conceito de errância para mostrar que a alma cessa de vaguear quando, apartada do corpo, contempla as coisas por si mesma. Ou seja, embora o afastamento do sentido comum das palavras e a entrada no reino da suprassensibilidade sejam causas diretas da aporia, a posse de uma ideia nos leva àquela estabilidade e concordância (homónoia) visadas no Alcibíades Maior. Dito noutros termos, quando o filósofo finalmente conquista a ideia, seu pensamento cessa de vaguear. O trecho do Fédon é de suma relevância porque sugere que o conceito de intermediário e sua consequente tripartição da alma em três classes, tal como o conceito de errância psíquica e de conhecimento enquanto estabilidade/acordo, estão no centro da chamada teoria das ideias e da divisão entre sensível e inteligível.

22. Sobre isso, o testemunho da Carta VII é eloquente, pois coloca o conhecimento como o estágio final de um árduo processo, ao longo do qual muitas dúvidas e obscuridades acometem o filósofo. A posse derradeira do conhecimento é definida como um evento arbitrário, que surge repentinamente (exaíphnēs) em nossa alma (Eps. VII, 341c4-d1). O mesmo é dito da visão do Belo no estágio final da scala amoris, a saber, que se trata de algo repentino e maravilhoso que surge ao filósofo (Conv. 201e2211a2).

23. No Parmênides, a errância psíquica é considerada etapa indispensável para que a verdade seja alcançada. Zenão afirma que, sem o percurso (diéxodou) e a errância (plánēs) através de todas as hipóteses, a verdade não pode ser conhecida (Parm. 136e1-3). 
Sócrates. Não dizíamos, ainda há pouco, que a alma utiliza às vezes o corpo para observar alguma coisa por intermédio da vista, ou do ouvido, ou de outro sentido? Assim o corpo é um instrumento, quando é por intermédio de algum sentido que se faz o exame da coisa, então a alma, dizíamos, é arrastada pelo corpo na direção daquilo que jamais guarda a mesma forma; ela mesma se torna inconstante (planâtai), agitada, e titubeia como se estivesse embriagada; isso, por estar em contato com coisa desse gênero.

Cebes. Realmente.

Sócrates. Mas quando, pelo contrário - nota bem! - ela examina as coisas por si mesma, quando se lança na direção do que é puro, do que sempre existe, do que nunca morre, do que se comporta sempre do mesmo modo - em virtude de seu parentesco com esses seres puros - é sempre junto deles que a alma vem ocupar o lugar a que lhe dá direito toda realização de sua existência em si mesma e por si mesma. Por isso, ela cessa de vaguear (plánou) e, na vizinhança dos seres de que falamos, passa ela também a conservar sempre sua identidade e seu mesmo modo de ser: é que está em contato com coisas desse gênero. Ora, este estado de alma, não é o que chamamos pensamento? $(P h d n .79 \mathrm{c} 2-\mathrm{d} 7)^{24}$.

Ademais, também pode-se concluir que tal doutrina não se restringe aos diálogos ditos da juventude, senão que permanece na obra madura de Platão, como evidenciado pelo Sofista. De fato, poder-se-ia estudar os inúmeros casos de aporia - no Mênon, no Hípias Maior, no Laques etc. - e mostrar que essa disposição precede o ato de filosofar e sempre implica a volubilidade de opiniões, a errância da alma e o reconhecimento da própria ignorância. A alegoria da caverna, que pressupõe estágios de conhecimento e, assim, o renovado sentimento de aporia ante as realidades que se revelam paulatinamente ao cavernícola, sugere a atuação contínua da ignorância. A libertação (lýsis) da caverna não é evento que, uma vez realizado, presenteia o filósofo com um conhecimento seguro e imutável sobre toda a realidade, senão um processo que deve ser posto em marcha em cada discussão que o filósofo empreende, pois as imperfeições de sua natureza empírica tendem continuamente a "puxá-lo para baixo", como Fedro, o Banquete e o Fédon sugerem. É nisto que consiste a carência do filósofo contida no prefixo phil-: na necessidade de buscar sempre de novo o objeto de seu desejo, a sabedoria.

Cabe dizer, por fim, que a unidade de todos esses pontos encontra-se no conceito de admiração (thaumázein), o páthos que caracteriza o início psíquico da filosofia. Isso, porém, seria tema para outro artigo.

24. Tradução de Jorge Paleikat e João Cruz Costa. Compara-se essa passagem com livro IV d'A República, onde Platão faz duas afirmações significativas sobre o filósofo, utilizando correlatos da ideia de errância psíquica. Primeiro, afirma que os filósofos "são capazes de atingir aquilo que se mantém sempre do mesmo modo", ao contrário dos que não são filósofos, os quais vagueiam (planốmenoi) nos domínios do múltiplo e variável (Rep. 484b3-6). E, mais para frente, reafirma que os filósofos estão sempre apaixonados pelo saber (máthèma) que lhes possa revelar a substância (ousía) que sempre existe, não aquela que é variável (planōmếnēs) em virtude da geração e da corrupção (Rep. 485a10-b3). Aqui novamente se reflete a diferença entre sensível e inteligível que compõe a passagem do Fédon. 


\section{BIBLIOGRAFIA}

ALBERT, K. Sul concetto di filosofia in Platone. 1. ed. Traduzzione italiana: Paola Traverso. Milano: Vita e Pensiero, 1991.

ALTMAN, W. The Guardians in Action: Plato the Teacher and the Post-Republic Dialogues from Timaeus to Theaetetus. Lanham: Lexington Books, 2016.

BURKERT, W. Platon oder Pythagoras? Zum Ursprung des Wortes "Philosophie". Hermes, Vol. 88, 1960, p. 159-177.

CHAPELL, T. Reading Plato's Theaetetus. Indianapolis: Hackett Publishing Company, Inc., 2005.

CHANTRAINE, P. Dictionnaire étymologique de la langue grecque. Paris: Klincksieck, 1999.

DONINI, P.; FERRARI, Franco. O exercício da razão no mundo clássico. São Paulo: Annablume Clássica, 2012.

ENGLER, M. R. ALTMAN, W. The Guardians in Action: Plato the Teacher and the Post-Republic Dialogues from Timaeus to Theaetetus. Lanham: Lexington Books, 2016 (Rezension), 2018 (no prelo).

. On Plato's interpretation of his philosophy: Phaedo's testimony on the diaphorá between poetry and philosophy. In: CORNELLI, G.; LOPES, R. IX Symposium Platonicum - Plato's Phaedo. Papers. International Plato Society; Annablume Classica, 2016, s/p.

GILSON, E. A filosofia na Idade Média. São Paulo: Martins Fontes, 1998.

GÓRGIAS [1999]. Elogio de Helena Trad.: Maria C. de Miranda N. Coelho. São Paulo: Cadernos de Tradução, n. 4, DF/USP.

.[1989] Reden, Fragmente und Testimonie. Herausgegebn mit Übersetzung und Kommentar von Thomas Buchheim. Hamburg: Feliz Meiner Verlag.

HAAR, M. A obra de arte. Ensaio sobre a ontologia das obras. Rio de Janeiro: Difel, 2000. HADOT, P. O que é a filosofia antiga? São Paulo: Loyola, 1999.

HALLIWELL, S. The aesthetics of mimesis: Ancient Texts and Modern Problems. Princeton: Princeton University Press, 2002. 
JAEGER, W. Paidéia: a formação do homem grego. $4^{a}$ edição. São Paulo: Martins Fontes, 2003.

KAHN, C. Plato and the Post-Socratic Dialogue. The Return to the Philosophy of Nature. Cambridge: Cambridge University Press, 2013.

KANT, I. Kritik der reinen Vernunft. Hamburg: Felix Meiner Verlag, 1967.

NUSSBAUM, M. A Fragilidade da Bondade: fortuna e ética na tragédia e na filosofia grega. São Paulo: Editora WMF Martins Fontes, 2009.

PLATÃO. Platonis Opera. Tomus I (org. E. A. Duke et alli). New York: Oxford University Press, 1995.

Press, First Published 1901.

. Platonis Opera. Tomus II (org. John Burnet) New York: Oxford University . Platonis Opera. Tomus III (org. John Burnet) New York: Oxford University Press, First Published 1903.

. Platonis Opera. Tomus IV (org. John Burnet) New York: Oxford University Press, First Published 1902.

. A República. Trad. Maria Helena da Rocha Pereira. Lisboa: Fundação Calouste Gulbenkian, 2001.

- Banquete. Trad. José Cavalcante de Souza. In: Pessanha, J. A. M. (seleção): Diálogos. São Paulo: Abril Cultural (Os pensadores), 1979.

- Eutífron. Trad. Enrico Corvisieri. São Paulo: Nova Cultural, (Os pensadores), 1999.

Defesa de Sócrates. Trad. Jaime Bruna. In: PESSANHA, J. A. M.(org.). Diálogos. São Paulo, Abril Cultural (Os Pensadores), 1979.

. Fédon. Trad. Jorge Paleikat e João Cruz Costa. In: Pessanha, J. A. M. (seleção): Diálogos. São Paulo: Abril Cultural (Os pensadores), 1979.

. Sofista. Trad. Jorge Paleikat e João Cruz Costa. In: Pessanha, J. A. M. (seleção): Diálogos. São Paulo: Abril Cultural (Os pensadores), 1979.

Hípias menor. Trad. Carlos Alberto Nunes. Belém: UFPA, 1986.

Hípias maior. Trad. Carlos Alberto Nunes. Belém: UFPA, 1980.

POPPER, K. A sociedade aberta e seus inimigos. São Paulo: Itatiaia, 1987. 
QUINE, W. V. O. Sobre o que há. In: Ensaios. São Paulo: Abril Cultura, 1975.

REALE, G. Eros dèmone mediatore. Il gioco dele maschere nel Simposio di Platone. Milano: RCS Libri S.p.A., 2000.

Storia dela Filosofia Antica. Platone e Aristotele. Vol. II. Milano: Vita e Pensiero, 1997.

ROSEN, S. Plato's Symposium. 2ª ed. New Haven: Yale University Press, 1987.

SEAGAL, C. P. Gorgias and the Psychology of the Logos. Harvard Studies in Classical Philology, Vol. 66 (1962), pp. 99-155.

SEDLEY, D. The midwife of Platonism. Text and subtext in Plato's Theaetetus. New York: Oxford University Press Inc., 2004.

SLEZÁK, T. A. Ler Platão. São Paulo: Loyola, 2005.

STRAUSS, L. The City and the Man. Chicago: Rond McNally \& Company, 1964. 